\title{
Interaction between toxic dinoflagellate Alexandrium catenella exposure and disease associated with herpesvirus OsHV-1 $\mu$ Var in Pacific oyster spat Crassostrea gigas
}

\author{
Lassudrie Malwenn ${ }^{1,{ }^{*}}$, Soudant Philippe ${ }^{1}$, Nicolas Jean-Louis ${ }^{2}$, Fabioux Caroline ${ }^{1}$, \\ Lambert Christophe ${ }^{1}$, Miner Philippe ${ }^{2}$, Le Grand Jacqueline ${ }^{3}$, Petton Bruno ${ }^{3}$, Hégaret Helene ${ }^{4}$
}

${ }^{1}$ Laboratoire des Sciences de l'Environnement Marin (LEMAR), UMR 6539 CNRS UBO IRD IFREMER

- Institut Universitaire Européen de la Mer, Technopôle Brest-Iroise - Rue Dumont d'Urville, 29280 Plouzané, France

2 Ifremer, Laboratoire des Sciences de l'Environnement Marin (LEMAR, UMR 6539 UBO/CNRS/IRD//fremer), Centre Bretagne - ZI de la Pointe du Diable - CS 10070, 29280 Plouzané, France

${ }^{3}$ Ifremer, Laboratoire des Sciences de l'Environnement Marin (LEMAR, UMR 6539 UBO/CNRS/IRD//fremer), Site Expérimental d'Argenton, 11 presqu'île du Vivier, 29840 Argenton-enLandunvez, France

* Corresponding author: Malwenn Lassudrie, Tel.: +33 298498861 ;

email address : malwenn.lassudrie@gmail.com

\begin{abstract}
:
Blooms of toxic dinoflagellates can co-occur with mass mortality events associated with herpesvirus OsHV-1 $\mu$ Var infection that have been decimating Pacific oyster Crassostrea gigas spat and juveniles every summer since 2008 in France. This study investigated the possible effect of a harmful dinoflagellate, Alexandrium catenella, a producer of Paralytic Shellfish Toxins (PSTs), upon the oyster spat-herpesvirus interaction. Oyster spat from a hatchery were challenged by cohabitation with oysters contaminated in the field with OsHV-1 $\mu$ Var and possibly other pathogens. Simultaneously, the oysters were exposed to cultured $A$. catenella. Infection with OsHV-1 $\mu$ Var and PST accumulation were measured after 4 days of experimental exposure.

Exposure to Alexandrium catenella modified the host-pathogen interaction by reducing prevalence of OsHV-1 $\mu$ Var infection. In addition, oysters challenged with OsHV-1 $\mu$ Var and possibly other pathogens from the environment accumulated smaller amounts of PSTs than unchallenged oysters. Three possible mechanisms are suggested by these results: (i) possible direct interactions between $A$. catenella and herpesvirus (or associated pathogens) could reduce viral transmission and algal availability for oyster consumption; (ii) oyster feeding behavior or digestive functions may have been altered, thus decreasing both uptake of viral particles and consumption or digestion of toxic algae and consequent toxin accumulation; (iii) immuno-activation by $A$. catenella could enhance defense efficiency against OsHV$1 \mu \mathrm{Var}$ infection. These findings suggest further research on relationships between OsHV-1 $\mu \mathrm{Var}$ and toxic dinoflagellates and their combined effects upon disease transmission and proliferation processes,
\end{abstract}


as well as on oyster physiological and immunological involvement in this complex, tripartite interaction.

\section{Highlights}

- Exposure to $A$. catenella and challenge by cohabitation with OsHV-1-infected oysters. catenella exposure for 4 days decreased OsHV-1 prevalence. Challenge by cohabitation with OsHV-1-infected oysters decreased toxin accumulation.

Keywords: Crassostrea gigas, OsHV-1 $\mu$ Var, Harmful algal blooms, Alexandrium, Host-pathogen interaction, PST accumulation 
45 Since 2008, French oyster production has been diminished by massive mortality events that

46 have decimated Crassostrea gigas spat ( $<12$ months old) and juveniles (12-18 months old),

47 when seawater temperature exceeds $16^{\circ} \mathrm{C}$. These mortality events decimate 40 to $100 \%$ of the

48 spat, depending upon location (Cochennec-Laureau et al., 2011; EFSA Panel on Animal

49 Health and Welfare, 2010; Fleury and Bédier, 2013; Fleury, 2014). Other countries in Europe,

50 as well as New Zealand, Australia and Korea also recently experienced massive spat and

51 juvenile oyster mortality events, which were associated with microvariants of ostreid

52 herpesvirus 1 (OsHV-1) (EFSA Panel on Animal Health and Welfare, 2010; Hwang et al.,

53 2013; Jenkins et al., 2013; Martenot et al., 2011; Paul-Pont et al., 2014; Renault et al., 2012).

54 The microvariant genotype detected in France, designated as OsHV-1 $\mu$ Var, was found also in 55 Ireland, the UK, Spain, the Netherlands, New Zealand and Australia (EFSA Panel on Animal 56 Health and Welfare, 2010; Gittenberger et al., 2015; Jenkins et al., 2013; Renault et al., 2012; 57 Roque et al., 2012; Segarra et al., 2010). A causal relationship between OsHV-1 $\mu$ Var and 58 mortality events has been postulated (Schikorski et al., 2011a, 2011b), although bacterial 59 strains from the Vibrio splendidus clade and Vibrio aesturianus also could be involved (EFSA 60 Panel on Animal Health and Welfare, 2010; Garnier et al., 2007; Gay et al., 2004), and 61 environmental factors and oyster physiological condition may play roles in disease severity 62 and oyster susceptibility to the disease (Pernet et al., 2014, 2012; Petton et al., 2013).

63 Concurrent with these mortality events, during spring and summer, toxic dinoflagellates 64 Alexandrium minutum and Alexandrium catenella recurrently bloom along the French coasts 65 (Amouroux et al., 2013; Belin et al., 2015; Chapelle et al., 2013; Fleury and Bédier, 2013; 66 Fleury, 2014; Lilly et al., 2002; REPHY; RESCO). Temperature thresholds above which 67 blooms usually are reported are in the range $15-18^{\circ} \mathrm{C}$ (Chapelle et al., 2013, 2007; Collos et 
68 al., 2009; Laabir et al., 2011), corresponding to temperature at which mortality events are

69 observed $\left(>16^{\circ} \mathrm{C}\right)$. For example, A. minutum blooms have occurred in the Bay of Brest (N.W.

70 of France) every summer since 2012 , with a maximum concentration of $42 \times 10^{6}$ cells $\mathrm{L}^{-1}$

71 detected in 2012 (Chapelle et al., 2013;

72 http://envlit.ifremer.fr/var/envlit/storage/documents/parammaps/phytoplancton/index.html);

73 and $69 \%$ cumulative oyster spat mortality was recorded there at the end of the summer this

74 year. In the Mediterranean sea, A. catenella blooms occur recurrently, including in the Thau

75 Lagoon (S. of France) where, for example, $2.5 \times 10^{5}$ cells $\mathrm{L}^{-1}$ were detected in June 2011

76 (Belin et al., 2012), concurrent with oyster spat mortality events mainly in May and June 2011

77 (for mortality reports in France by year and site, see RESCO website,

78 http://wwz.ifremer.fr/observatoire_conchylicole/Resultats-nationaux). Both these

79 Alexandrium species can produce Paralytic Shellfish Toxins (PSTs). Bivalves, as filter-

80 feeders, can accumulate PSTs, leading to toxicity for human shellfish consumers and thus

81 resulting in temporary shellfish harvest prohibitions. Species of the genus Alexandrium can

82 also produce extracellular compounds with allelopathic, hemolytic, ichtyotoxic, and oxidative

83 properties (Arzul et al., 1999; Flores et al., 2012; Lelong et al., 2011). Interactions between

84 bivalves and Alexandrium sp. - and thus PSTs and extracellular compounds - have been

85 examined in many studies. Alterations of physiological processes and tissue integrity have

86 been reported in bivalves after a few hours to a few (4-9) days of exposure to Alexandrium sp.

87 cells $\left(10^{2}-10^{3}\right.$ cell $\left.\mathrm{mL}^{-1}\right)($ Cucci et al., 1985; Gainey and Shumway, 1988a, 1988b; Galimany

88 et al., 2008a; Haberkorn et al., 2010b; Landsberg, 2002; Lassudrie et al., 2014; Medhioub et

89 al., 2012; Shumway, 1990). Hemocytes, which are involved in many functions including

90 immunity, also are affected by Alexandrium sp. within a few days of exposure (Galimany et

91 al., 2008a; Haberkorn et al., 2010a; Hégaret et al., 2007). By altering cell functions involved

92 in immune response, physiological processes and tissue integrity in bivalves, Alexandrium sp. 
93 may modify shellfish susceptibility to pathogens. Indeed, Lassudrie et al. (2015) reported that

94 a three-week exposure to Alexandrium fundyense (a PST producer) resulted in modified

95 immune functions associated with higher susceptibility to infection with the protozoan

96 parasite Perkinsus marinus in trematode-infested Eastern oysters. On the contrary, da Silva et

97 al. (2008) reported a decrease in intensity of Perkinsus olseni infection in Manila clams

98 exposed to the toxic dinoflagellate Karenia selliformis for 2 weeks, which was shown to result

99 from direct toxicity of algae to P. olseni. Similarly, Hégaret et al. (2010) suggested a toxic

100 effect of the dinoflagellate Prorocentrum minimum upon the protistan Quahog Parasite

101 Unknown (QPX) in northern quahog clams. Thus, toxic algal exposure may modify the host-

102 pathogen interaction, either by affecting host physiological or immune status, or through

103 direct toxicity to the pathogen.

104 Despite the importance of OsHV-1 $\mu$ Var in oyster mortality events in France and the repeated co-occurrence with harmful algal blooms, to the best of our knowledge, the effect of toxic

106 algal exposure upon the oyster spat - herpesvirus interaction has not been described.

107 The aim of this study was, thus, to assess if and how exposure to the toxic dinoflagellate, $A$. 108 catenella could modulate the host-pathogen interaction, i.e. oyster spat - herpesvirus 109 interaction. For this purpose, oyster spat naïve from herpesvirus (Specific Pathogen-Free, 110 SPF) were exposed simultaneously to cultured A. catenella (at realistic concentrations 111 compared to the field) and challenged with herpesvirus and possible other pathogenic agents 112 associated with mortality events. 


\section{Material and methods}

\subsection{Algal cultures}

115 Tisochrysis lutea (Bendif \& Probert) (T-Iso) was used as the diet during acclimation and

116 maintenance stages at $5 \times 10^{5}$ cells $\mathrm{mL}^{-1}$. T-Iso was cultured in 300 -L cylinders containing

117 seawater enriched with Conway medium (Walne, 1966) at $20^{\circ} \mathrm{C}$ with continuous light (200

$118 \mu \mathrm{mol}$ photons $\mathrm{m}^{-2} \mathrm{~s}^{-1}$ ). T-Iso was harvested after 3 to 5 days of growth, at a cell density 119 approaching $1 \times 10^{7}$ cells $\mathrm{mL}^{-1}$.

120 The dinoflagellate Alexandrium catenella (Whedon \& Kofoid) strain VGO676, a PST 121 producer (Lassus et al., 2007) isolated in 2003 from Thau lagoon (France), was used for toxic 122 algal exposure, and Heterocapsa triquetra (Ehrenberg) Stein, strain HT99PZ (isolated from 123 Penzé Bay, France in 1999) was used as a control, non-toxic dinoflagellate. Both strains were 124 provided by the Phycotoxin laboratory, Ifremer, Nantes (France). Both dinoflagellate cultures 125 were grown in L1 medium (Guillard and Hargraves, 1993) at $17^{\circ} \mathrm{C}$ with a light:dark cycle of $12612: 12 \mathrm{~h}$ and were harvested during exponential growth phase at a cell density approaching $5 \times$ $12710^{4}$ cells $\mathrm{mL}^{-1}$.

128 Algal cell densities were determined by counts using Malassez and Nageotte cells under a 129 light microscope.

131 2.2 Specific Pathogen-Free (SPF) oysters

132 The Pacific oysters, Crassostrea gigas (Thunberg), used in this study came from a single 133 cohort produced in March 2012 in the Argenton Ifremer facilities (France) following a 
134 standardized process to obtain OsHV-1-free diploid-oysters described by Petton et al. (2013).

135 Screening for OsHV-1 DNA (i.e. OsHV-1 reference as well as OsHV-1 $\mu$ Var) was conducted 136 by qPCR (following the standard procedure described in Pépin et al., 2008) once during D-

137 larval stage and again at 3 months of age following thermal challenge; all results were 138 negative for this cohort (analyses by IDHESA, Quimper, France). At the time the experiment 139 began (July 2012), oysters were 4 months old, measured $23.1 \pm 0.2 \mathrm{~mm}$ length (mean $\pm \mathrm{SE}$ ), 140 and weighed $1.45 \pm 0.3 \mathrm{~g}$ (total wet weight; mean $\pm \mathrm{SE}$ ).

\subsection{OsHV-1 contamination by field-exposure}

143 On June $18^{\text {th }}, 2012$, a subsample of SPF oyster spat ( $\left.n=1000\right)$ was transferred into the Bay of 144 Brest, at Pointe du Chateau (48 20'06.19' N, $4^{\circ} 19^{\prime} 06.37^{\prime}$ W), in a farming area with 145 recurrent mass mortality of oysters (Fleury and Bédier, 2013; Fleury, 2014; François et al., 146 2010). This time corresponded with the highest peak of spat mortality in this location in 2012 $147 \quad(30-34 \%$ instantaneous mortality)

(RESCO,

148 http://wwz.ifremer.fr/observatoire_conchylicole/Resultats-nationaux/Resultats-nationaux-

149 2012/Mortalite-par-site-et-par-classe-d-age). After 3 weeks in the field (i.e. July $2^{\text {nd }}, 2012$ ), 150 detection of OsHV-1 DNA in experimental oysters was confirmed by qPCR (following the 151 procedure described below), and oysters were transferred to the experimental facilities. 152 Oysters were held for three days before the beginning of the experiment in two tanks supplied 153 with an open flow of $1-\mu \mathrm{m}$-filtered seawater treated with $\mathrm{UV}$, at $20^{\circ} \mathrm{C}$, and fed continuously 154 with T-Iso at 3-5 $\times 10^{5}$ cell $\mathrm{mL}^{-1}$. One hundred and eighty field-exposed oysters then were 155 used to challenge SPF oysters by cohabitation, as described below, and were also analyzed 156 (designated as "field-exposed oysters"). The same number of SPF oysters was maintained in 
157 two other tanks in the same conditions, and these oysters were used for cohabitation with 158 unchallenged oysters.

\subsection{Experimental design}

161 On June $25^{\text {th }}, 2012$, SPF oysters were distributed in $15-\mathrm{L}$ tanks (30 oysters per tank, 12 tanks)

162 and acclimated for 10 days being fed T-Iso. At the end of this acclimation period, on July $5^{\text {th }}$

$163\left(\mathrm{~T}_{0}\right), 30$ field-exposed oysters per tank, held in a net, were added to six of these tanks. The

164 SPF oysters that were thus maintained in cohabitation with the field-exposed oysters were 165 designated as "challenged". In the six other tanks, 30 other SPF oysters per tank, held in a net, 166 were added to establish the same number of oysters in each tank. The oysters in these tanks 167 were designated as "unchallenged". In addition, 3 "challenged" tanks and 3 "unchallenged" 168 tanks were exposed continuously to $3.5 \times 10^{2}$ cells $\mathrm{mL}^{-1}$ of the toxic dinoflagellate $A$. 169 catenella; whereas, the other tanks were exposed to the same concentration of the control, 170 non-toxic dinoflagellate, $H$. triquetra.

171 Experimental design is summarized in Figure 1. Four experimental conditions were used: $A$. 172 catenella exposure and challenged oysters (condition 1); A. catenella exposure and 173 unchallenged oysters (condition 2); non-toxic algal exposure and challenged oysters 174 (condition 3); non-toxic algal exposure and unchallenged oysters (condition 4).

175 A similar cohabitation design previously has been demonstrated to successfully infect SPF 176 oysters with the pathogenic agents responsible for mass mortality, including OsHV-1 $\mu$ Var 177 (Petton et al., 2013). 
178 During the entire experiment, $1-\mu \mathrm{m}$-filtered and UV-treated seawater was supplied to the 179 tanks $\left(10-15 \mathrm{~mL} \mathrm{~min}^{-1}\right.$, i.e. one tank renewal every $\left.24 \mathrm{~h}\right)$ with aeration at $20^{\circ} \mathrm{C}$, a temperature 180 favorable for OsHV-1 $\mu$ Var transmission (Petton et al., 2013).

\subsection{Sampling}

183 Oysters were sampled at the end of the acclimation period, i.e. before the beginning of the 184 experiment $\left(\mathrm{T}_{0}\right)$, and after four days $\left(\mathrm{T}_{4}\right)$. At $\mathrm{T}_{0}, 12$ field exposed-oysters, 12 SPF oysters from 185 "unchallenged" tanks (2 per tank), and 12 SPF oysters from "challenged" tanks (2 per tank) 186 were sampled. At $\mathrm{T}_{4}, 72$ unchallenged oysters (12 per tank), 72 challenged oysters (12 per 187 tank), and 72 field-exposed oysters from "challenged" tanks (12 per tank) were sampled.

188 Mantle and digestive gland were sampled for herpesvirus and toxin quantification, 189 respectively, and tissue samples were frozen immediately in liquid nitrogen before being 190 stored at $-80^{\circ} \mathrm{C}$ prior to quantification.

191 Oyster mortality was checked daily. Dead oysters were removed from the tanks, and mantle 192 and digestive gland were dissected, when the degradation stage of the tissue allowed it, and 193 stored at $-80^{\circ} \mathrm{C}$ for further analyses.

194 Not all oysters sampled were used for each analysis (see sections below). 
197 OsHV-1 DNA was quantified in the mantle at the end of the acclimation period $\left(\mathrm{T}_{0}\right)$ (before

198 algal exposure and cohabitation challenge) in 2 SPF oysters per tank, which were designated

199 to be challenged (i.e. 12 oysters) and 1 oyster per tank designated to remain unchallenged (i.e.

2006 oysters) to confirm oysters were not contaminated at the beginning of the experiment.

201 Additionally, 11 field-exposed oysters were also analyzed at $\mathrm{T}_{0}$ to confirm that contamination

202 occurred in the field. After four days of the experiment, OsHV-1 quantification was performed

203 in 36 and 35 challenged oysters exposed to $H$. triquetra and A. catenella, respectively (11-12

204 oysters per tank), in 23 and 24 field-exposed oysters exposed to H. triquetra and A. catenella, respectively (7-8 oysters per tank); and in 3 unchallenged oysters per algal condition (one per tank) as these oysters were not expected to be contaminated. Analysis also was performed for 20725 of the 27 field-exposed oysters and for all the 5 challenged oysters that died over the 208 course of the experiment.

209 DNA extraction was performed with the QIAamp DNA Mini Kit (QIAgen), analyzing 20 mg 210 of wet mantle, following the manufacturer instructions. $100 \mu \mathrm{L}$ of molecular biology grade 211 water (DNase-free) were used for elution. Nucleic acid concentration was measured 212 immediately with a NanoDrop® ND-1000 UV-Vis Spectrophotometer (conversion factor: 1 $\left.213 \mathrm{OD}=50 \mu \mathrm{g} \mathrm{mL}^{-1} \mathrm{DNA}\right)$ at $260 \mathrm{~nm}$ and adjusted at $3 \mathrm{ng} \mu \mathrm{L}^{-1}$ after purity was checked using 214 the $260 / 230 \mathrm{~nm}$ and $260 / 280 \mathrm{~nm}$ ratios.

215 A standard protocol was followed to quantify OsHV-1 DNA (OsHV-1 reference as well as 216 OsHV-1 $\mu$ Var) using qPCR (Pépin, 2013; Pépin et al., 2008) with the HVDP-F - HVDP-R 217 primer pair (forward, HVDP-F 5'-ATT-GAT-GAT-GTG-GAT-AAT-CTG-TG-3', reverse, 218 HVDP-R 5'-GGT-AAA-TAC-CAT-TGG-TCT-TGT-TCC-3'), targeting the OsHV-1 219 polymerase sequence. Each reaction was performed in triplicate and carried out in a final 220 volume of $15 \mu \mathrm{L}$ containing HVDP-F and HVDP-R primers at final concentrations of $5 \mu \mathrm{M}$, 
$2217.5 \mu \mathrm{L}$ of IQ SYBR Green Supermix and $5 \mu \mathrm{L}$ of DNA samples diluted at $3 \mathrm{ng} \mu \mathrm{L}^{-1}$. Each run

222 included a no-template control (water), a positive control (DNA from OsHV-1-infected

223 oyster), and six standards (from $10^{5}$ to $10^{0}$ OsHV-1 copies $\mu \mathrm{L}^{-1}$ ), prepared by successive, ten-

224 fold dilutions of a stock solution of OsHV-1 genomic DNA at $5 \times 10^{6}$ copies $\mu \mathrm{L}^{-1}$ extracted

225 from purified virus particles (Le Deuff and Renault, 1999). The standard curve obtained was

226 used to calculate the percentage of amplification efficiency (\% E) described in (1), which was

227 contained between $90 \%$ and $110 \%$, and quantification of the samples was determined by 228 comparing Ct values.

229 (1) $\% \mathrm{E}=\left(10^{-1 / a}-1\right) \times 100$, with $a=$ slope of the linear regression line calculated from $\mathrm{Ct}=$ $230 \mathrm{f}\left(\log _{10}\right.$ of dilution).

231 An MyIQ2 Thermocycler (Biorad) was used with the following thermal profile: 1 cycle of 232 enzyme activation $\left(95^{\circ} \mathrm{C}, 3 \mathrm{~min}.\right), 40$ cycles of amplification/detection $\left(95^{\circ} \mathrm{C}, 30 \mathrm{~s} ; 60^{\circ} \mathrm{C}\right.$, $\left.2331 \mathrm{~min} . ; 72^{\circ} \mathrm{C}, 1 \mathrm{~min}\right)$, and a final step for melting temperature curve analysis $\left(80\right.$ cycles, $95^{\circ} \mathrm{C}$ 234 to $55^{\circ} \mathrm{C}$, decreasing the temperature by $0.5^{\circ} \mathrm{C}$ after each cycle, $10 \mathrm{~s}$ ). The specificity of the 235 PCR products was checked systematically with the melting temperature (Tm) value calculated 236 from the dissociation curve.

237 Results were expressed as number of OsHV-1 DNA copies $\mathrm{ng}^{-1}$ total DNA. In addition, 238 quantification expressed as OsHV-1 DNA copies $\mathrm{mg}^{-1}$ of wet mantle was determined. 239 Correlation between both ways of expressing OsHV1 DNA quantification was verified 240 (Pearson product moment correlation, $p<0.001$, correlation coefficient $=0.98, \mathrm{n}=269$ ).

241 The following criteria were used to consider OsHV-1 detection as positive: $\mathrm{Ct}<38$ and a Tm 242 corresponding to OsHV-1 DNA amplicon $\left(77.5^{\circ} \mathrm{C}\right)$. When OsHV-1 DNA concentration in 
243 samples considered as positive were below the detection limit (i.e. $\mathrm{Ct}_{\text {sample }}>\mathrm{Ct}_{\text {standards }}$ ), a

244 numerical value of 0 was given for quantification.

247 The standard qPCR method used to quantify OsHV-1 DNA cannot differentiate the OsHV-1

248 reference from OsHV-1 $\mu$ Var genotype. Therefore, sequencing of 2 regions of OsHV-1 DNA 249 amplified with C2/C6 and IA1/IA2 primer pairs was performed following the procedure 250 described by Segarra et al. (2010). This analysis was performed on DNA extracted from the 251 mantle of 10 individuals, including both field-exposed and challenged oysters, exposed to 252 both algal treatments, alive and dead. Comparison of the nucleotide sequences obtained with 253 OsHV1 reference and OsHV1 $\mu$ Var sequences confirmed the sole presence of the OsHV1 $\mu$ Var 254 genotype in the samples. Considering both this analysis and the report of OsHV-1 $\mu$ Var having 255 replaced OsHV-1 reference genotype since 2009 in spat at French rearing sites suffering mass 256 mortality (including Bay of Brest), (François et al., 2010; Petton et al., 2013; Renault et al., 257 2012), the OsHV-1 genotype in the present study was considered to be OsHV-1 $\mu$ Var.

\subsection{Toxin accumulation}

260 Three SPF oysters at $\mathrm{T}_{0}$ and 3 oysters exposed to the non toxic $H$. triquetra and not previously

261 held in the field were tested to ensure that no PST was detected. 23 challenged and 23 262 unchallenged-oysters (7-8 oysters per tank) were analyzed after 4 days of A. catenella263 exposure. Twelve field-exposed oysters also were analyzed for toxin accumulation at $\mathrm{T}_{0}$, as 
264 well as 12 field-exposed oysters from each algal treatment at $\mathrm{T}_{4}$ (4 oysters per tank), PST

265 analysis also was performed after A. catenella exposure on 8 of the 12 dead field-exposed 266 oysters, and in the 3 dead oysters unexposed to the field.

267 PST accumulation was assessed using the Saxitoxin (PSP) ELISA kit (Abraxis), as in 268 Lassudrie et al. (2015). PST extraction was performed following manufacturer instructions:

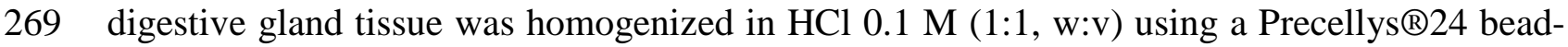
270 grinder and then boiled for $5 \mathrm{~min}$, leading to acid hydrolysis that can induce chemical 271 conversion of some PST analogues to STX (Vale et al., 2008). Indeed, this ELISA assay 272 recognizes mostly STX, and other PSTs only to varying degrees (cross-reactivities of 100\%

273 for STX and $<30 \%$ for other PSTs). Therefore, PST content was expressed as $\mu \mathrm{g} \mathrm{STX} \mathrm{kg} \mathrm{of}^{-1}$ 274 wet digestive gland weight.

276 2.9 Statistical analyses

277 For all statistical tests, absence of difference between replicate tanks was first verified before 278 comparing different conditions.

279 To compare cumulative mortality curves (Kaplan Meier method) between conditions, a Log280 rank (Mantel-Cox) test followed by multiple comparison tests with Holm-Bonferroni 281 correction was used.

282 Difference between OsHV-1 prevalence in live oysters according to algal exposure was tested 283 with a Chi-square test. 
284 In live oysters, effect of algal treatment (A. catenella or H. triquetra), and effect of time of 285 sampling in field-exposed oysters were tested upon OsHV-1 DNA quantification with a $t$-test. 286 OsHV-1 DNA data were $\log _{10}(\mathrm{X}+1)$ transformed to obtain normality of residuals and 287 homogeneity of variances. A $\log _{10}$ scale was used in graphical representation of OsHV-1 DNA 288 data.

289 Differences in PST accumulation in digestive glands were tested with a Mann-Whitney test to 290 compare challenged and unchallenged oysters, and with a Kruskal-Wallis test followed by a 291 Nemenyi-Damico-Wolfe-Dunn (NDWD) post-hoc test to compare field-exposed oysters at $\mathrm{T}_{0}$, 292 after 4 days of exposure to $A$. catenella and after 4 days of exposure to $H$. triquetra.

293 Differences were considered significant when $p<0.05$. Statistical analyses were performed 294 using Statgraphics Plus statistical software (Manugistics, Inc., Rockville, MD, USA), R 295 version 2.15.1 (R Core Team, 2012) and GraphPad Prism. All values were expressed as mean $296 \pm$ standard error. 


\section{Results}

298

299

\subsection{Mortality}

300 Cumulative mortality (Figure 2) accounted for $16.7 \%$ and $13.3 \%$ of field-exposed oysters 301 after 4 days of exposure to $H$. triquetra and A. catenella, respectively. After 4 days of the 302 experiment, $3.3 \%$ and $2.2 \%$ mortality was found in challenged oysters exposed to $H$. triquetra 303 and A. catenella, respectively; whereas $2.8 \%$ and $0.6 \%$ mortality were found in unchallenged 304 oysters exposed to $H$. triquetra and A. catenella, respectively. Cumulative mortality was 305 significantly higher $(p<0.05)$ in field-exposed oysters compared to unchallenged oysters fed 306 both $A$. catenella and $H$. triquetra, and challenged-oysters fed A. catenella. Cumulative 307 mortality in field-exposed oysters, however, did not differ significantly from cumulative 308 mortality in challenged oysters fed $H$. triquetra.

311 Within the dead oysters:

312 OsHV-1 DNA was detected in $100 \%$ of the dead oysters, either previously exposed to the field

$313\left(1.1 \pm 0.2 \times 10^{6}\right.$ copies $\mathrm{ng}^{-1}$ total DNA, equivalent to $2.5 \pm 0.5 \times 10^{9}$ copies $\mathrm{mg}^{-1}$ of wet 314 mantle, $\mathrm{n}=25)$ or challenged $\left(1.0 \pm 1.0 \times 10^{5}\right.$ copies $\mathrm{ng}^{-1}$ total DNA, equivalent to $2.0 \pm 2.0 \times$ $31510^{8}$ copies $\mathrm{mg}^{-1}$ of wet mantle, $\mathrm{n}=5$ ). In dead, unchallenged oysters, OsHV-1 was detected in 3 316 of 4 oysters, but only at low intensity levels (between $6.6 \times 10^{0}$ and $2.9 \times 10^{2}$ copies $^{-1}$ total 317 DNA). 
318 Within live oysters:

319 OsHV-1 DNA was not detected in SPF oysters sampled at the end of the acclimation period

$320\left(\mathrm{~T}_{0} ; \mathrm{n}=12\right.$ oysters from tanks designated to be challenged and $\mathrm{n}=6$ oysters from tanks 321 designated to remain unchallenged) or in unchallenged oysters sampled after 4 days of 322 experimental treatment $(\mathrm{n}=6)$.

323 OsHV-1 DNA was detected in all field-exposed oysters sampled at $\mathrm{T}_{0}(\mathrm{n}=11)$, with a mean of $4.9 \pm 3.010^{5}$ copies $\mathrm{ng}^{-1}$ total DNA in mantle $\left(1.2 \pm 0.810^{9}\right.$ copies $\mathrm{mg}^{-1}$ of wet mantle) (N.B: field-exposed oysters were unintentionally exposed to a natural, unexpected A. minutum bloom). In field-exposed oysters, prevalence did not decrease significantly between $\mathrm{T}_{0}$ and after 4 days of experiment $(98 \%, n=47)$ and did not vary significantly with experimental algal exposure. OsHV-1 infection intensity in field-exposed oysters, however, decreased significantly between $\mathrm{T}_{0}$ and after 4 days of $A$. catenella exposure $(p<0.05)\left(9.6 \pm 9.2 \times 10^{2}\right.$ copies $\mathrm{ng}^{-1}$ total DNA, or $2.7 \pm 2.5 \times 10^{6}$ copies $\mathrm{mg}^{-1}$ of wet mantle, $\mathrm{n}=23$ ), but not after $H$.

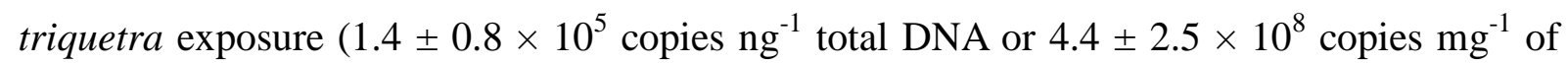
wet mantle, $n=23)$. Therefore, OsHV-1 intensity level was significantly lower in field-exposed oysters exposed to A. catenella compared to field-exposed oysters exposed to $H$. triquetra $(p<0.05)$.

In challenged oysters, at $\mathrm{T}_{4}$, OsHV-1 prevalence was significantly lower $(p<0.05)$ after exposure to A. catenella (29\%) compared to H. triquetra (58\%, Figure 3A). OsHV-1 infection intensity (i.e. OsHV-1 DNA quantification considering only oysters detected positive to OsHV-1) tended to be lower in A. catenella-exposed oysters with $7.0 \pm 5.6 \times 10^{2}$ copies $^{-1}{ }^{-1}$

339 total DNA (or $1.9 \pm 1.5 \times 10^{6}$ copies $\mathrm{mg}^{-1}$ of wet mantle, $\mathrm{n}=10$ ), compared to $2.8 \pm 2.5 \times 10^{4}$ 340 copies $\mathrm{ng}^{-1}$ total DNA (or $6.4 \pm 5.6 \times 10^{7}$ copies $\mathrm{mg}^{-1}$ of wet mantle, $\mathrm{n}=21$ ) in oysters exposed 
341 to $H$. triquetra, although no significant difference was detected (Figure 3B). Finally, a

342 significantly lower OsHV-1 weighted prevalence (i.e. mean of OsHV-1 DNA quantification in 343 oysters, considering OsHV-1-positive and OsHV-1-negative oysters) was detected in $A$. 344 catenella-exposed oysters $(p<0.05)\left(2.0 \pm 1.6 \times 10^{2}\right.$ copies $\mathrm{ng}^{-1}$ total DNA or $5.4 \pm 4.5 \times 10^{5}$

345 copies $\mathrm{mg}^{-1}$ of wet mantle, $\mathrm{n}=35$ ) compared to oysters exposed to the non-toxic $H$. triquetra $346\left(1.6 \pm 1.5 \times 10^{4}\right.$ copies $\mathrm{ng}^{-1}$ total DNA or $3.7 \pm 3.3 \times 10^{7}$ copies $\mathrm{mg}^{-1}$ of wet mantle, $\left.\mathrm{n}=36\right)$ 347 (Figure 3B).

\subsection{Toxin accumulation}

350 No PST was detected in digestive glands of SPF oysters sampled at $T_{0}(n=3)$ and after 4 days exposure to the non toxic dinoflagellate $H$. triquetra $(\mathrm{n}=3)$.

352 In field-exposed oysters, PST level at $\mathrm{T}_{0}$ was $8.8 \pm 1.3 \times 10^{3} \mu \mathrm{g} \mathrm{STX} \mathrm{kg}^{-1}(\mathrm{n}=12)$ due to a 353 natural, unexpected A. minutum bloom. PST level decreased significantly more after 4 days of 354 H. triquetra exposure $\left(2.9 \pm 0.6 \times 10^{3} \mu \mathrm{g} \mathrm{STX} \mathrm{kg}{ }^{-1} ; \mathrm{n}=12\right)$ than after A. catenella exposure 355 $\left(5.3 \pm 0.4 \times 10^{3} \mu \mathrm{g} \mathrm{STX} \mathrm{kg}^{-1} ; \mathrm{n}=12\right)(p<0.01)$

356 After 4 days of $A$. catenella exposure, significantly lower PST accumulation $(p<0.05)$ was 357 detected in digestive gland of challenged oysters $\left(3.6 \pm 0.6 \times 10^{2} \mu \mathrm{g}\right.$ STX kg$\left.{ }^{-1}, \mathrm{n}=23\right)$ 358 compared to unchallenged oysters $\left(6.9 \pm 1.1 \times 10^{2} \mu \mathrm{g} \mathrm{STX} \mathrm{kg}{ }^{-1}, \mathrm{n}=23\right)$ (Figure 4).

359 PSTs were not detected in the 3 dead oysters exposed to A. catenella ( 2 challenged and 1 360 unchallenged, dead after 3 days of experiment) that were analyzed, whereas $9.7 \pm 2.1 \times 10^{3}$ $361 \mu \mathrm{g} \mathrm{STX} \mathrm{kg}{ }^{-1}$ were detected after A. catenella exposure in field-exposed oysters that died 
362 during the experiment (previously exposed to a natural, unexpected A. minutum bloom in the 363 field) (n=8). 
366 Exposure to A. catenella was shown for the first time to reduce herpesvirus infection;

367 furthermore, PST accumulation decreased in oysters challenged with the herpesvirus and 368 possibly also other pathogenic agents associated with mortality. These interactions constitute 369 an antagonistic relationship between the virus and the toxic alga when they co-occur.

370 Responses of oysters may result from direct interactions between OsHV-1 $\mu$ Var and $A$. 371 catenella and their toxic compounds, or may be the consequence of immune and 372 physiological responses to the virus and / or the microalga.

374 Low cumulative mortality (from $2.2 \%$ to $16.7 \%$ depending upon experimental treatment) was 375 observed in the present study after 4 days of experimental treatment at $20^{\circ} \mathrm{C}$. Using a similar 376 cohabitation design, Petton et al. (2013) tested the effect of temperature upon mortality 377 kinetics. Cumulative mortality observed in the present study was in a similar range to that 378 reported by Petton et al. (2013), who observed no mortality in challenged oysters and $~ 8 \%$ in 379 field-exposed oysters after 4 days at $17.5^{\circ} \mathrm{C}$. Cumulative mortality observed in our study, 380 however, was lower than that observed after 4 days at $21.9^{\circ} \mathrm{C}$ by Petton et al. (2013), who 381 reported $\sim 20 \%$ mortality in challenged oysters and $40 \%$ in field-exposed oysters. These 382 authors also observed higher mortality in oyster spat previously held in the field during mass 383 mortality events than in challenged oysters, which is consistent with our study. All oysters 384 exposed to the field or challenged by cohabitation with field-exposed oysters that died during 385 the experiment were infected with OsHV-1. Some dead, unchallenged oysters contained very 386 low levels of OsHV-1 DNA. Seawater supplied, however, was sterilized by UV treatment, 
suggesting that a low cross-contamination between tanks may have occurred through aerosols.

388 The very low intensity detected in dead, unchallenged oysters $\left(\leq 2.9 \times 10^{2}\right.$ copies $\mathrm{ng}^{-1}$ total DNA), compared with dead, field-exposed or challenged oysters $\left(10^{5}\right.$ to $10^{6}$ copies $\mathrm{ng}^{-1}$ total DNA) indicated that death was not related to OsHV-1 infection. Additionally, contamination was not detected in any of the live, unchallenged oysters analyzed throughout the experiment, suggesting a minor impact of putative cross-contamination.

393 The relatively low infective biomass (i.e. field-exposed oysters) used, and the short 394 cohabitation time limited mortality in challenged oysters (for more information about 395 influence of infective biomass and duration of cohabitation see Petton et al., 2015). These 396 conditions were implemented to allow the study of live oysters containing sub-lethal levels of 397 OsHV-1 $\mu$ Var, based upon results reported by Petton et al. (2013). These authors detected 398 OsHV-1 DNA in $50 \%$ of oysters challenged for 3 days at $21.9^{\circ} \mathrm{C}$, a result consistent with the $39958 \%$ detection found in the present study in challenged oysters exposed to the non-toxic 400 dinoflagellate for 4 days, at $20^{\circ} \mathrm{C}$.

401 Exposure to the toxic dinoflagellate A. catenella, however, significantly reduced the 402 prevalence of OsHV-1 $\mu$ Var from $58 \%$ to $29 \%$. Exposure to A. catenella also induced a 403 significant decrease of OsHV-1 $\mu$ Var weighted prevalence and a non significant decrease of 404 the infection intensity in challenged oysters. In field-oysters unintentionally exposed to a 405 natural $A$. minutum bloom prior to the experiment, an experimental A. catenella exposure 406 decreased OsHV-1 $\mu$ Var intensity compared to non-toxic algal conditions. These results 407 suggest an effect of $A$. catenella: (i) upon proliferation and virulence mechanisms of OsHV$4081 \mu$ Var, through modulation of oyster immune responses, (ii) upon horizontal transmission of 409 OsHV-1 $\mu$ Var, either through direct interaction between the virus and the algal cells, or by 410 modulating the oyster feeding processes. 
411 Proliferation of OsHV-1 $\mu$ Var may have been inhibited by activation of the host immune

412 responses induced by A. catenella exposure. Although immune defense against herpesvirus is

413 not well documented, hemocyte-mediated responses appear to be involved, as shown by

414 hemocyte infiltrations (Jenkins et al., 2013) and differentially expressed genes related to

415 hemocyte functions in virus-infected oysters (Green et al., 2014; Jouaux et al., 2013; Renault

416 et al., 2011). Previous studies showed an inflammatory response in bivalves exposed to

417 Alexandrium sp., which increased circulating hemocyte concentration, as well as hemocyte

418 infiltration and diapedesis, particularly in the digestive gland but also in the gills and the

419 mantle (Galimany et al., 2008a; Haberkorn et al., 2010a, 2010b; Lassudrie et al., 2014). More

420 numerous hemocytes in these organs that are also targeted by OsHV-1 (Corbeil et al., 2015;

421 Schikorski et al., 2011a) could result in a faster, more efficient defense and accelerate

422 elimination of herpesvirus, possibly through release of humoral factors. For example, $\alpha 2$ -

423 macroglobulin molecules are protease inhibitors expressed in hemocytes that play a role in the

424 immune defense (Gueguen et al., 2003; Vaseeharan et al., 2007), and are upregulated with

425 herpesvirus infection in C. gigas (Jouaux et al., 2013). Increase in hemocyte apoptosis

426 induced by A. catenella (Medhioub et al., 2013) also may play a role, as apoptosis is an

427 important component of immune defense against intra-cellular pathogens by limiting their 428 proliferation (Everett and McFadden, 1999; Sokolova, 2009), and appears to be involved in 429 response to OsHV-1 (Jouaux et al., 2013). Exposure to Alexandrium sp. also can increase 430 oxidative stress in bivalves, which could alter the integrity of the lipid-containing envelope of 431 herpesvirus particles. In fact, exposure to Alexandrium spp. modulated antioxidant 432 mechanisms (enzyme activity or gene expression) in clams and oysters (Estrada et al., 2007; 433 Lassudrie et al., 2014; Romero-Geraldo and Hernández-Saavedra, 2012), and increased 434 observations of ceroid bodies (containing oxidized molecules) in tissues (Galimany et al., 435 2008b; Lassudrie et al., 2014). Oxidation of the viral envelope could decrease virus viability, 
436 but also may alter entry mechanisms into the host cells, as well as interfering with viral

437 replication (Lorizate and Kräusslich, 2011).

438 Cells of Alexandrium spp. have been reported to produce extracellular compounds with 439 allelopathic, hemolytic, ichtyotoxic, and oxidative properties, that can have deleterious effects 440 upon different target cells (Arzul et al., 1999; Flores et al., 2012; Lelong et al., 2011). Toxic 441 effects of extracellular compounds of A. catenella toward OsHV-1 $\mu$ Var particles could occur 442 through lysis or oxidation of the virus lipid-containing envelope and affect transmission 443 process directly in the water column. In fact, Paul-Pont et al. (2013) and Evans et al. (2014) 444 hypothesized that horizontal transmission of OsHV-1 $\mu$ Var would be promoted by planktonic 445 cells carrying the virus. Thus, by damaging the herpesvirus particle envelope, A. catenella 446 extracellular compounds may have decreased the viable viral particle load carried by algal 447 cells and consequently reduced the viable viral load entering the host oyster.

448 Another hypothesis to explain a lower transmission of OsHV-1 $\mu$ Var particles in oysters 449 exposed to A. catenella, is based upon the effects of Alexandrium spp. exposure upon bivalve 450 feeding activities. Indeed, filtration, clearance, and ingestion rates were reported to be reduced 451 during exposure to toxigenic algae (Cucci et al., 1985; Lassus et al., 1999; Shumway and 452 Cucci, 1987). Such effects could limit the introduction of viral particles into the organism. A 453 similar, hypothetic relationship between filtration rate and herpesvirus load has already been 454 proposed by Schikorski et al. (2011a).

456 Challenge of Specific Pathogen-Free (SPF) oysters by cohabitation with field-exposed oysters 457 led to a lower PST accumulation after exposure to A. catenella, compared with unchallenged 458 oysters. The difference in PST accumulation between challenged and unchallenged oysters 
suggests that exposure to an environment with pathogens either: (i) affected the oyster

460 filtration or ingestion rates or the digestive processes resulting in different PST load; or (ii)

461 reduced the availability and / or the digestibility of the A. catenella cells.

462 The first hypothesis involves nutrition and digestion processes. Recent results of an 463 experimental study suggested that food ingestion or absorption can be affected by OsHV-1 $464 \mu$ Var and possible other pathogens associated with mortality events, as lower sterol contents 465 were observed in oysters exposed to these pathogens (Tamayo et al., 2014). These authors 466 also described oyster responses that mimicked food deprivation associated with the disease, as 467 indicated by the utilization of proteins for energetic requirements following glycogen 468 depletion. Depleted energetic reserves, coincident with mass mortality events in the field 469 (Pernet et al., 2014), could be a consequence of stimulation of glycolysis and lipolysis by 470 OsHV-1 $\mu$ Var infection, as suggested by a recent proteomic study (Corporeau et al., 2014). 471 Additionally, ulcerative lesions of mantle and gill epithelium were observed in OsHV-1472 infected oysters C. gigas, in Australia (Jenkins et al., 2013), possibly interfering with filtration 473 and sorting involved in feeding. Altogether, findings from the present and recent studies could 474 indicate alteration of feeding processes and digestive functions by viral or bacterial infections 475 affecting $A$. catenella consumption by challenged oysters.

476 Finally, as mentioned previously, the interaction of $A$. catenella cells with micro-organisms 477 carried by-field exposed oysters could have reduced availability or digestibility of the algal 478 cells prior to filtration. In fact, bacteria can produce bio-active compounds with algicidal 479 properties or exopolymers that may enhance algal cell sinking and degradation (see review of 480 Doucette, 1995). In addition, when subjected to a stress, some dinoflagellates, including 481 Alexandrium sp., are able to rapidly form temporary cysts, which can still be ingested by filter 482 feeders; however, impenetrable cyst walls protect them from being digested and thus limit 
483 toxin release (Hégaret et al., 2008; Laabir et al., 2007; Persson et al., 2006). Thus, a stressful 484 effect of extra-cellular bacterial production also could have induced encystment of $A$. 485 catenella cells, thereby decreasing their digestibility and resulting in lower toxin 486 accumulation in the oyster digestive gland. 


\section{Conclusions}

488 This study revealed that A. catenella can significantly impact the C. gigas - herpesvirus 489 interaction. Additionally, the herpes virus infection, and / or putative associated microbiota, 490 can change interactions between oysters and A. catenella and decrease oyster PST 491 accumulation, demonstrating the complexity of such tripartite interaction.

492 The results show that $A$. catenella could partially inhibit transmission or proliferation of 493 herpesvirus if a bloom occurs at the initial stage of the infection. The effect upon mortality 494 events associated with OsHV-1 $\mu$ Var, however, remains to be investigated in situ, although 495 these results suggest that an A. catenella bloom could delay the mortality outbreaks.

496 Further research focusing on direct interactions between toxic dinoflagellates and OsHV-1, as

497 well as on oyster immune- and physiologically-related processes would be needed to better 498 understand the mechanisms involved in this tripartite interaction and better project 499 consequences upon oyster industry. 
501 This work was supported by ANR CESA (ACCUTOX project) and by CNRS PICS (Pathotox 502 project). M. Lassudrie was supported by a doctoral grant from Université de Bretagne 503 Occidentale. OsHV-1 DNA standards were kindly provided by Ifremer La Tremblade 504 (France). Patrick Lassus (Phycotoxin laboratory, Ifremer Nantes, France) is acknowledged for 505 providing $A$. catenella and $H$. triquetra strains. The authors also thank Marie-Agnès Travers 506 for technical advise and discussions, Nelly Le Goïc, Anne-Laure Cassone and Ludovic 507 Hermabessière for technical assistance, Benjamin Morga for help with OsHV-1 $\mu$ Var 508 identification, and Ika Paul-Pont and Gary H. Wikfors for constructive comments and 509 assistance with English editing. 
Amouroux, I., Belin, C., Claisse, D., Daniel, A., Fleury, E., Mao, P. Le, Miossec, L., 2013. Qualité du Milieu Marin Littoral Synthèse Nationale de la Surveillance 2012. Ifremer report.

Arzul, G., Seguel, M., Guzman, L., Erard-Le Denn, E., 1999. Comparison of allelopathic properties in three toxic Alexandrium species. J. Exp. Mar. Bio. Ecol. 232, 285-295.

Belin, C., Claisse, D., Daniel, A., Fleury, E., Miossec, L., Ropert, M., 2015. Qualité du Milieu Marin Littoral Synthèse Nationale de la Surveillance 2013. Ifremer report.

Belin, I.C., Claisse, D., Daniel, A., Fleury, E., Mao, P. Le, Marchand, M., Nedellec, M., Boisseaux, A., Soudant, D., 2012. Qualité du Milieu Marin Littoral Synthèse Nationale de la Surveillance 2011. Ifremer report.

Chapelle, A., Andrieux, F., Fauchot, J., Guillaud, J.F., Labry, C., Sourisseau, M., Verney, R., 2007. Comprendre, Prédire et Agir sur les efflorescences toxiques. Jusqu'où peut-on aller aujourd'hui dans le cas d'Alexandrium minutum en Penzé? Ifremer report.

Chapelle, A., Le Bec, C., Le Gac, M., Labry, C., Amzil, Z., Guillou, L., Dreanno, C., Pineau, L., Siano, R., Youénou, A., Quéré, J., Savar, V., Destombes, C., Dia, A., Lazure, P., Petton, S., Le Brun, L., Abernot, C., Duval, A., Doner, A., Gouriou, J., Le Gal, D., Terrre, A., 2013. Etude sur la prolifération de la micro algue Alexandrium minutum en rade de Brest Projet Daoulex Rapport d'avancement $n^{\circ}$ 1: Novembre 2013. Ifremer report.

Cochennec-Laureau, N., Baud, J.-P., Pépin, J.-F., Benabdelmouna, A., Soletchnik, P., Lupo, C., Garcia, C., Arzul, I., Boudry, P., Huvet, A., Pernet, F., Bachere, E., Bedier, E., Petton, B., Gaussem, F., Stanisiere, J.-Y., Degremont, L., 2011. Les surmortalités des naissains d'huîtres creuses, Crassostrea gigas: acquis des recherches en 2010. Ifremer report.

Collos, Y., Bec, B., Jauzein, C., Abadie, E., Laugier, T., Lautier, J., Pastoureaud, A., Souchu, P., Vaquer, A., 2009. Oligotrophication and emergence of picocyanobacteria and a toxic dinoflagellate in Thau lagoon, southern France. J. Sea Res. 61, 68-75.

Corbeil, S., Faury, N., Segarra, A., Renault, T., 2015. Development of an in situ hybridization assay for the detection of ostreid herpesvirus type 1 mRNAs in the Pacific oyster, Crassostrea gigas. J. Virol. Methods 211, 43-50.

Corporeau, C., Tamayo, D., Pernet, F., Quéré, C., Madec, S., 2014. Proteomic signatures of the oyster metabolic response to herpesvirus OsHV-1 $\mu$ Var infection. J. Proteomics 109C, $176-187$.

Cucci, T.L., Shumway, S.E., Newell, R.C., Yentsch, M., 1985. A preliminary study of the effects of Gonyaulax tamarensis on feeding in bivalve molluscs, in: Anderson, D.M., White, A.W., Baden, D.G. (Eds.), Toxic Dinoflagellates. Elsevier/North-Holland, Amsterdam, pp. 395-400. 
da Silva, P.M., Hégaret, H., Lambert, C., Wikfors, G.H., Le Goïc, N., Shumway, S.E., Soudant, P., 2008. Immunological responses of the Manila clam (Ruditapes philippinarum) with varying parasite (Perkinsus olseni) burden, during a long-term exposure to the harmful alga, Karenia selliformis, and possible interactions. Toxicon 51 , $563-573$

Doucette, G.J., 1995. Interactions between bacteria and harmful algae: a review. Nat. Toxins $3,65-74$.

EFSA Panel on Animal Health and Welfare, 2010. Scientific Opinion on the increased mortality events in Pacific oyster, Crassostrea gigas. EFSA 8, 1894.

Estrada, N., de Jesús Romero, M., Campa-Córdova, A., Luna, A., Ascencio, F., 2007. Effects of the toxic dinoflagellate, Gymnodinium catenatum on hydrolytic and antioxidant enzymes, in tissues of the giant lions-paw scallop Nodipecten subnodosus. Comp. Biochem. Physiol. Part C 146, 502-510.

Evans, O., Paul-Pont, I., Hick, P., Whittington, R.J., 2014. A simple centrifugation method for improving the detection of Ostreid herpesvirus-1 (OsHV-1) in natural seawater samples with an assessment of the potential for particulate attachment. J. Virol. Methods 210, 5966.

Everett, H., McFadden, G., 1999. Apoptosis: an innate immune response to virus infection. Trends Microbiol. 7, 160-165.

Fleury, É., 2014. RESCO - Réseau d'Observations Conchylicoles: Campagne 2013. Ifremer report.

Fleury, É., Bédier, É., 2013. RESCO - Réseau d'Observations Conchylicoles: Campagne 2012. Ifremer report.

Flores, H.S., Wikfors, G.H., Dam, H.G., 2012. Reactive oxygen species are linked to the toxicity of the dinoflagellate Alexandrium spp. to protists. Aquat. Microb. Ecol. 66, 199209.

François, C., Joly, J., Garcia, C., Miossec, L., Saulnier, D., Pépin, J.F., Arzul, I., Omnes, E., Tourbiez, D., Haffner, P., Chollet, B., Robert, M., Cobret, L., Renault, T., Rauflet, F., Le Gagneur, E., Ropert, M., Mouillard, G., Gerla, D., Annezo, J.P., Le Gal, D., Langlade, A., Bédier, E., Breerette, S., Chabirand, J.M., Grizon, J., Robert, S., Courtois, O., Rumebe, M., 2010. Bilan 2009 du réseau REPAMO - Réseau national de surveillance de la santé des mollusques marins. Ifremer report.

Gainey, L.F., Shumway, S.E., 1988a. Physiological effects of Protogonyaulax tamarensis on cardiac activity in bivalves molluscs. Comp. Biochem. Physiol. Part C 91, 159-164.

Gainey, L.F., Shumway, S.E., 1988b. A compendium of the responses of bivalve molluscs to toxic dinoflagellates. J. Shellfish Res. 7, 623-628. 
Galimany, E., Sunila, I., Hégaret, H., Ramón, M., Wikfors, G.H., 2008a. Experimental exposure of the blue mussel (Mytilus edulis, L.) to the toxic dinoflagellate Alexandrium fundyense: Histopathology, immune responses, and recovery. Harmful Algae 7, 702-711.

Galimany, E., Sunila, I., Hégaret, H., Ramón, M., Wikfors, G.H., 2008b. Pathology and immune response of the blue mussel (Mytilus edulis L.) after an exposure to the harmful dinoflagellate Prorocentrum minimum. Harmful Algae 7, 630-638.

Garnier, M., Labreuche, Y., Garcia, C., Robert, M., Nicolas, J.L., 2007. Evidence for the involvement of pathogenic bacteria in summer mortalities of the Pacific oyster Crassostrea gigas. Microb. Ecol. 53, 187-196.

Gay, M., Renault, T., Pons, A.M., Le Roux, F., 2004. Two Vibrio splendidus related strains collaborate to kill Crassostrea gigas: taxonomy and host alterations. Dis. Aquat. Org. Org. 62, 65-74.

Gittenberger, A., Voorbergen-Laarman, M.A., Engelsma, M.Y., 2015. Ostreid herpesvirus OsHV-1 $\mu$ Var in Pacific oysters Crassostrea gigas (Thunberg 1793) of the Wadden Sea, a UNESCO world heritage site. J. Fish Dis.

Green, T.J., Montagnani, C., Benkendorff, K., Robinson, N., Speck, P., 2014. Ontogeny and water temperature influences the antiviral response of the Pacific oyster, Crassostrea gigas. Fish Shellfish Immunol. 36, 151-157.

Gueguen, Y., Cadoret, J.P., Flament, D., Barreau-Roumiguière, C., Girardot, A.L., Garnier, J., Hoareau, A., Bachère, E., Escoubas, J.M., 2003. Immune gene discovery by expressed sequence tags generated from hemocytes of the bacteria-challenged oyster, Crassostrea gigas. Gene 303, 139-145.

Guillard, R.R.L., Hargraves, P.E., 1993. Stichochrysis immobilis is a diatom, not a chrysophyte. Phycologia 32, 234-236.

Haberkorn, H., Lambert, C., Le Goïc, N., Guéguen, M., Moal, J., Palacios, E., Lassus, P., Soudant, P., 2010a. Effects of Alexandrium minutum exposure upon physiological and hematological variables of diploid and triploid oysters, Crassostrea gigas. Aquat. Toxicol. 97, 96-108.

Haberkorn, H., Lambert, C., Le Goïc, N., Moal, J., Suquet, M., Guéguen, M., Sunila, I., Soudant, P., 2010b. Effects of Alexandrium minutum exposure on nutrition-related processes and reproductive output in oysters Crassostrea gigas. Harmful Algae 9, 427439.

Hégaret, H., Shumway, S.E., Wikfors, G.H., Pate, S., Burkholder, J., 2008. Potential transport of harmful algae via relocation of bivalve molluscs. Mar. Ecol. Prog. Ser. 361, 169-179.

Hégaret, H., Smolowitz, R.M., Sunila, I., Shumway, S.E., Alix, J., Dixon, M., Wikfors, G.H., 2010. Combined effects of a parasite, QPX, and the harmful-alga, Prorocentrum minimum on northern quahogs, Mercenaria mercenaria. Mar. Environ. Res. 69, 337-344. 
Hégaret, H., Wikfors, G.H., Soudant, P., Lambert, C., Shumway, S.E., Bérard, J.B., Lassus, P., 2007. Toxic dinoflagellates (Alexandrium fundyense and A. catenella) have minimal apparent effects on oyster hemocytes. Mar. Biol. 152, 441-447.

Hwang, J.Y., Park, J.J., Yu, H.J., Hur, Y.B., Arzul, I., Couraleau, Y., Park, M. a, 2013. Ostreid herpesvirus 1 infection in farmed Pacific oyster larvae Crassostrea gigas (Thunberg) in Korea. J. Fish Dis. 36, 969-972.

Jenkins, C., Hick, P., Gabor, M., Spiers, Z., Fell, S., Gu, X., Read, A., Go, J., Dove, M., O'Connor, W., Kirkland, P., Frances, J., 2013. Identification and characterisation of an ostreid herpesvirus-1 microvariant (OsHV-1 $\mu$-var) in Crassostrea gigas (Pacific oysters) in Australia. Dis. Aquat. Organ. 105, 109-126.

Jouaux, A., Lafont, M., Blin, J.L., Houssin, M., Mathieu, M., Lelong, C., 2013. Physiological change under OsHV-1 contamination in Pacific oyster Crassostrea gigas through massive mortality events on fields. BMC Genomics 14, 590.

Laabir, M., Amzil, Z., Lassus, P., Masseret, E., Tapilatu, Y., De Vargas, R., Grzebyk, D., 2007. Viability, growth and toxicity of Alexandrium catenella and Alexandrium minutum (Dinophyceae) following ingestion and gut passage in the oyster Crassostrea gigas. Aquat. Living Ressources 20, 51-57.

Laabir, M., Jauzein, C., Genovesi, B., Masseret, E., Grzebyk, D., Cecchi, P., Vaquer, A., Perrin, Y., Collos, Y., 2011. Influence of temperature, salinity and irradiance on the growth and cell yield of the harmful red tide dinoflagellate Alexandrium catenella colonizing Mediterranean waters. J. Plankton Res. 33, 1550-1563.

Landsberg, J.H., 2002. The effects of harmful algal blooms on aquatic organisms. Rev. Fish. Sci. 10, 113-390.

Lassudrie, M., Soudant, P., Henry, N., Medhioub, W., da Silva, P.M., Donval, A., Bunel, M., Le Goïc, N., Lambert, C., de Montaudouin, X., Fabioux, C., Hégaret, H., 2014. Physiological responses of Manila clams Venerupis (=Ruditapes) philippinarum with varying parasite Perkinsus olseni burden to toxic algal Alexandrium ostenfeldii exposure. Aquat. Toxicol. 154, 27-38.

Lassudrie, M., Wikfors, G.H., Sunila, I., Alix, J.H., Dixon, M.S., Combot, D., Soudant, P., Fabioux, C., Hégaret, H., 2015. Physiological and pathological changes in the eastern oyster Crassostrea virginica infested with the trematode Bucephalus sp. and exposed to the toxic dinoflagellate Alexandrium fundyense. J. Invertebr. Pathol. 126, 51-63.

Lassus, P., Amzil, Z., Baron, R., Séchet, V., Barillé, L., Abadie, E., Bardouil, M., Sibat, M., Truquet, P., Bérard, J., Gueguen, M., 2007. Modelling the accumulation of PSP toxins in Thau Lagoon oysters (Crassostrea gigas) from trials using mixed cultures of Alexandrium catenella and Thalassiosira weissflogii. Aquat. Living Ressources 67, 5967. 
Lassus, P., Bardouil, M., Beliaeff, B., Masselin, P., Naviner, M., Truquet, P., 1999. Effect of continuous supply of the toxic dinoflagellate Alexandrium minutum Halim on the feeding behaviour of the Pacific oyster (Crassostrea gigas Thunberg). J. Shellfish Res. 18, 211216.

Le Deuff, R.M., Renault, T., 1999. Purification and partial genome characterization of a herpes-like virus infecting the Japanese oyster, Crassostrea gigas. J. Gen. Virol. 80, $1317-1322$.

Lelong, A., Haberkorn, H., Le Goïc, N., Hégaret, H., Soudant, P., 2011. A new insight into allelopathic effects of Alexandrium minutum on photosynthesis and respiration of the diatom Chaetoceros neogracile revealed by photosynthetic-performance analysis and flow cytometry. Microb. Ecol. 62, 919-930.

Lilly, E.L., Kulis, D.M., Gentien, P., Anderson, D.M., 2002. Paralytic shellfish poisoning toxins in France linked to a human-introduced strain of Alexandrium catenella from the western Pacific: evidence from DNA and toxin analysis. J. Plankton Res. 24, 443-452.

Lorizate, M., Kräusslich, H.G., 2011. Role of Lipids in Virus Replication. Cold Spring Harb. Perspect. Biol. 3, a004820.

Martenot, C., Oden, E., Travaillé, E., Malas, J.P., Houssin, M., 2011. Detection of different variants of Ostreid Herpesvirus 1 in the Pacific oyster, Crassostrea gigas between 2008 and 2010. Virus Res. 160, 25-31.

Medhioub, W., Lassus, P., Truquet, P., Bardouil, M., Amzil, Z., Sechet, V., Sibat, M., Soudant, P., 2012. Spirolide uptake and detoxification by Crassostrea gigas exposed to the toxic dinoflagellate Alexandrium ostenfeldii. Aquaculture 358-359, 108-115.

Medhioub, W., Ramondenc, S., Vanhove, A.S., Vergnes, A., Masseret, E., Savar, V., Amzil, Z., Laabir, M., Rolland, J.L., 2013. Exposure to the neurotoxic dinoflagellate, Alexandrium catenella, induces apoptosis of the hemocytes of the oyster, Crassostrea gigas. Mar. Drugs 11, 4799-4814.

Paul-Pont, I., Dhand, N.K., Whittington, R.J., 2013. Spatial distribution of mortality in Pacific oysters Crassostrea gigas: reflection on mechanisms of OsHV-1 transmission. Dis. Aquat. Organ. 105, 127-138.

Paul-Pont, I., Evans, O., Dhand, N.K., Rubio, A., Coad, P., Whittington, R.J., 2014. Descriptive epidemiology of mass mortality due to Ostreid herpesvirus-1 (OsHV-1) in commercially farmed Pacific oysters (Crassostrea gigas) in the Hawkesbury River estuary, Australia. Aquaculture 422-423, 146-159.

Pépin, J.F., 2013. Short technical report for OsHV-1 detection and quantification by Real Time Polymerase Chain Reaction using OsHV-1 DNA polymerase sequence. Ifremer report. 
Pépin, J.F., Riou, A., Renault, T., 2008. Rapid and sensitive detection of ostreid herpesvirus 1 in oyster samples by real-time PCR. J. Virol. Methods 149, 269-276.

Pernet, F., Barret, J., Le Gall, P., Corporeau, C., Dégremont, L., Lagarde, F., Pépin, J.F., Keck, N., 2012. Mass mortalities of Pacific oysters Crassostrea gigas reflect infectious diseases and vary with farming practices in the Mediterranean Thau lagoon, France. Aquac. Environ. Interact. 2, 215-237.

Pernet, F., Lagarde, F., Jeannée, N., Daigle, G., Barret, J., Le Gall, P., Quéré, C., Roque D'orbcastel, E., 2014. Spatial and temporal dynamics of mass mortalities in oysters is influenced by energetic reserves and food quality. PLoS One 9, e88469.

Persson, A., Smith, B.C., Wikfors, G.H., Quilliam, M., 2006. Grazing on toxic Alexandrium fundyense resting cysts and vegetative cells by the eastern oyster (Crassostrea virginica). Harmful Algae 5, 678-684.

Petton, B., Boudry, P., Alunno-Bruscia, M., Pernet, F., 2015. Factors influencing diseaseinduced mortality of Pacific oysters Crassostrea gigas. Aquac. Environ. Interact. 6, 205222.

Petton, B., Pernet, F., Robert, R., Boudry, P., 2013. Temperature influence on pathogen transmission and subsequent mortalities in juvenile Pacific oysters Crassostrea gigas. Aquac. Environ. Interact. 3, 257-273.

R Core Team, 2012. R: A language and environment for statistical computing. R Foundation for Statistical Computing, Vienna, Austria. ISBN 3-900051-07-0, URL: http://www.rproject.org/.

Renault, T., Faury, N., Barbosa-Solomieu, V., Moreau, K., 2011. Suppression substractive hybridisation ( $\mathrm{SSH}$ ) and real time PCR reveal differential gene expression in the Pacific cupped oyster, Crassostrea gigas, challenged with Ostreid herpesvirus 1. Dev. Comp. Immunol. 35, 725-735.

Renault, T., Moreau, P., Faury, N., Pépin, J.F., Segarra, A., Webb, S., 2012. Analysis of clinical ostreid herpesvirus 1 (Malacoherpesviridae) specimens by sequencing amplified fragments from three virus genome areas. J. Virol. 86, 5942-5947.

REPHY (Phytoplankton and Phycotoxins monitoring network for French coastal waters) [WWW Document].

URL http://envlit.ifremer.fr/var/envlit/storage/documents/synoptique_toxine/PSP/perMonth/in dex.html

RESCO. Réseau d'Observations Conchylicole (French Monitoring Network for Shellfish Farming) [WWW Document].

URL http://wwz.ifremer.fr/observatoire_conchylicole_eng/ 
Romero-Geraldo, R. de J., Hernández-Saavedra, N.Y., 2012. Stress gene expression in Crassostrea gigas (Thunberg, 1793) in response to experimental exposure to the toxic dinoflagellate Prorocentrum lima (Ehrenberg) Dodge, 1975. Aquac. Res. 1-11.

Roque, A., Carrasco, N., Andree, K.B., Lacuesta, B., Elandaloussi, L., Gairin, I., Rodgers, C.J., Furones, M.D., 2012. First report of OsHV-1 microvar in Pacific oyster (Crassostrea gigas) cultured in Spain. Aquaculture 324-325, 303-306.

Schikorski, D., Faury, N., Pépin, J.F., Saulnier, D., Tourbiez, D., Renault, T., 2011a. Experimental ostreid herpesvirus 1 infection of the Pacific oyster Crassostrea gigas: Kinetics of virus DNA detection by q-PCR in seawater and in oyster samples. Virus Res. $155,28-34$.

Schikorski, D., Renault, T., Saulnier, D., Faury, N., Moreau, P., Pépin, J.F., 2011b. Experimental infection of Pacific oyster Crassostrea gigas spat by ostreid herpesvirus 1: demonstration of oyster spat susceptibility. Vet. Res. 42, 27.

Segarra, A., Pépin, J.F., Arzul, I., Morga, B., Faury, N., Renault, T., 2010. Detection and description of a particular Ostreid herpesvirus 1 genotype associated with massive mortality outbreaks of Pacific oysters, Crassostrea gigas, in France in 2008. Virus Res. 153, 92-99.

Shumway, S.E., 1990. A review of the effects of algal blooms on shellfish and aquaculture. J. World Aquac. Soc. 21, 65-104.

Shumway, S.E., Cucci, T.L., 1987. The effects of the toxic dinoflagellate Protogonyaulax tamarensis on the feeding and behaviour of bivalve molluscs. Aquat. Toxicol. 10, 9-27.

Sokolova, I.M., 2009. Apoptosis in molluscan immune defense. Invertebr. Surviv. J. 6, 49-58.

Tamayo, D., Corporeau, C., Petton, B., Quéré, C., Pernet, F., 2014. Physiological changes in Pacific oyster Crassostrea gigas exposed to the herpesvirus OsHV-1 $\mu$ Var. Aquaculture 432, 304-310.

Vale, C., Alfonso, A., Vieytes, M.R., Romarís, X.M., Arévalo, F., Botana, A.M., Botana, L.M., 2008. In vitro and in vivo evaluation of paralytic shellfish poisoning toxin potency and the influence of the $\mathrm{pH}$ of extraction. Anal. Chem. 80, 1770-1776.

Vaseeharan, B., Lin, Y.-C., Ko, C.-F., Chiou, T.-T., Chen, J.-C., 2007. Molecular cloning and characterisation of a thioester-containing alpha2-macroglobulin (alpha2-M) from the haemocytes of mud crab Scylla serrata. Fish Shellfish Immunol. 22, 115-130.

Walne, P.R., 1966. Experiments in the large-scale culture of the larvae of Ostrea edulis L., Fishery In. ed. Her Majesty's Stationery Office, London. 


\section{Figure captions}

762 Figure 1. Scheme of the experimental design. All oysters used were produced in hatchery in 763 conditions naive from OsHV-1 and were designated as Specific Pathogen-Free (SPF). SPF 764 and field-exposed oysters were sampled prior to exposure and cohabitation $\left(\mathrm{T}_{0}\right)$; field-exposed 765 oysters, challenged and unchallenged oysters were sampled after 4 days of algal exposure and 766 cohabitation $\left(\mathrm{T}_{4}\right)$.

767 Figure 2. Kaplan-Meier cumulative mortality curves in oyster spat according to field768 exposure, challenged (cohabitation with field-exposed oysters) or unchallenged, and algal 769 exposure (Ht: Heterocapsa triquetra or Ac: Alexandrium catenella). Significant differences 770 between mortality curves are indicated by letters (Log-rank test adjusted with Holm771 Bonferroni correction for multiple comparisons; $p<0.05)$. At $\mathrm{T}_{0}, \mathrm{~N}=90$ field-exposed oysters 772 per algal treatment, 90 challenged oysters per algal treatment and 180 unchallenged oysters 773 per algal treatment.

774 Figure 3. (A) OsHV-1 prevalence in challenged oyster spat, after 4 days exposure to the non775 toxic Heterocapsa triquetra or the toxic Alexandrium catenella. * indicates a statistical 776 difference between conditions (Chi-square test; $p<0.05$ ). $\mathrm{N}$ is indicated in each bar. (B)

777 OsHV-1 infection intensity (considering only challenged oysters detected positive to OsHV-1) 778 and weighted prevalence (considering all challenged oysters), quantified in the mantle after 4 779 days exposure to the non-toxic $H$. triquetra or the toxic $A$. catenella. * indicates a statistical 780 difference ( $t$-test; $p<0.05)$. Mean $\pm \mathrm{SE} . \mathrm{N}$ is indicated in each bar. 
781 Figure 4. Paralytic Shellfish Toxin (PST) accumulation after 4 days of exposure to 782 Alexandrium catenella in the digestive glands of live, unchallenged or challenged oyster spat.

783 * indicates a significant difference between conditions (Mann-Whitney test; $p<0.05$ ). Mean \pm 784 SE. $\mathrm{N}=23$ per condition. 


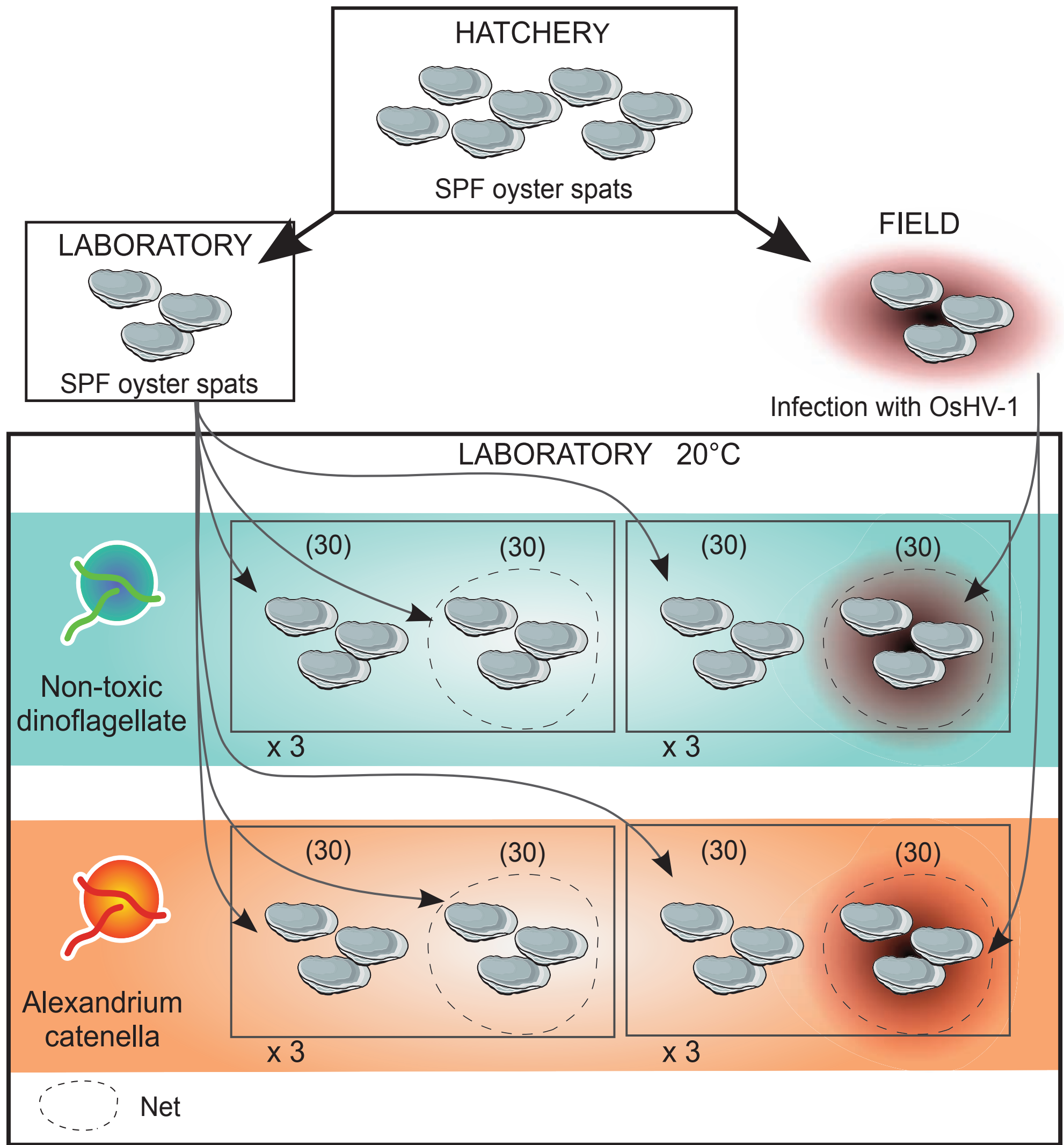




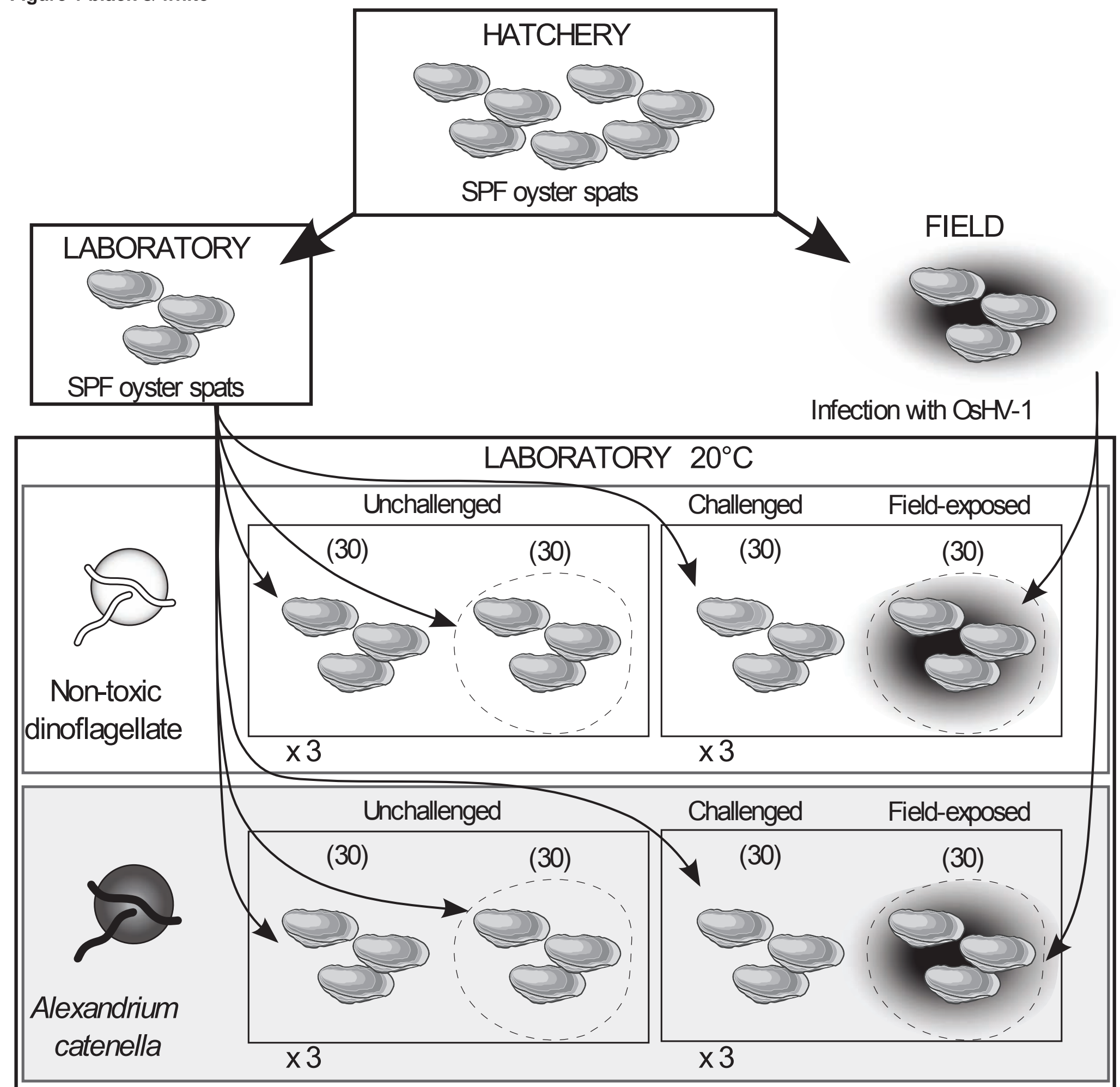

Net 


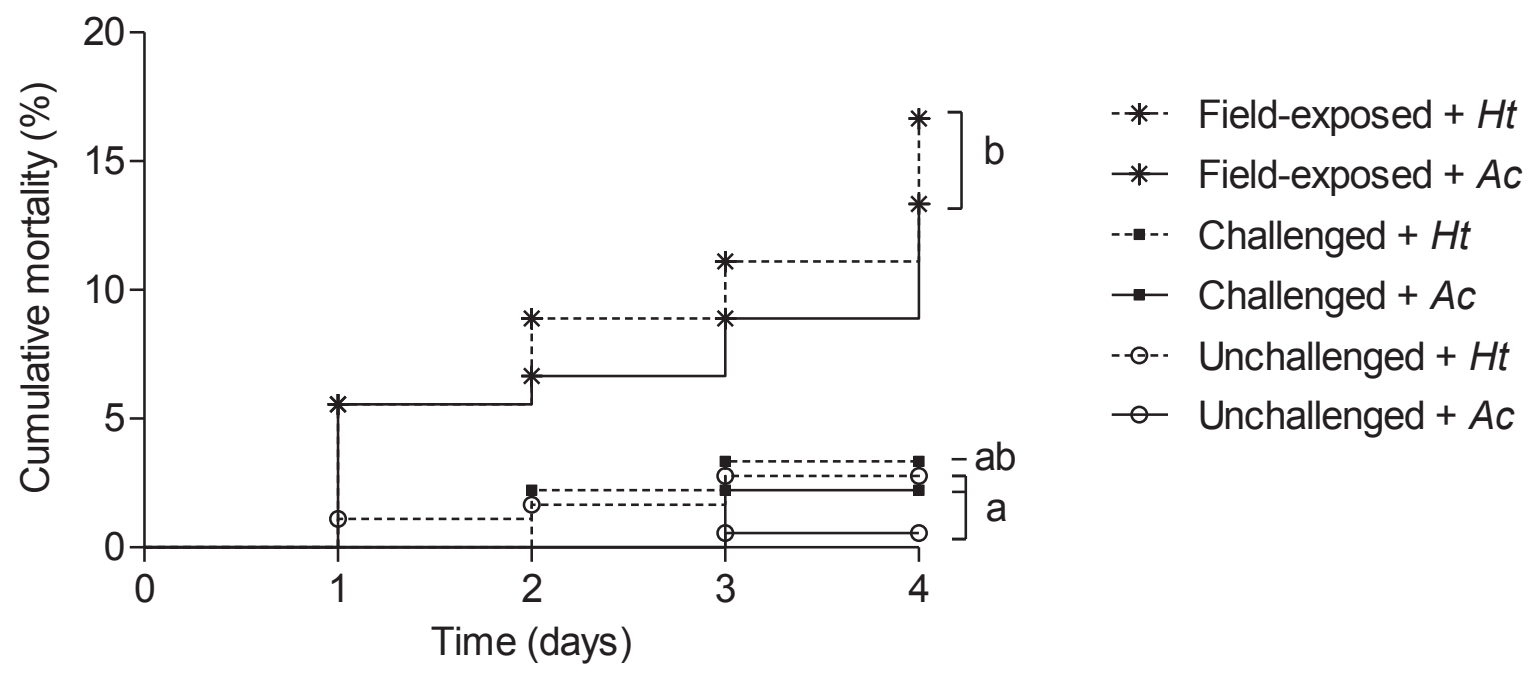



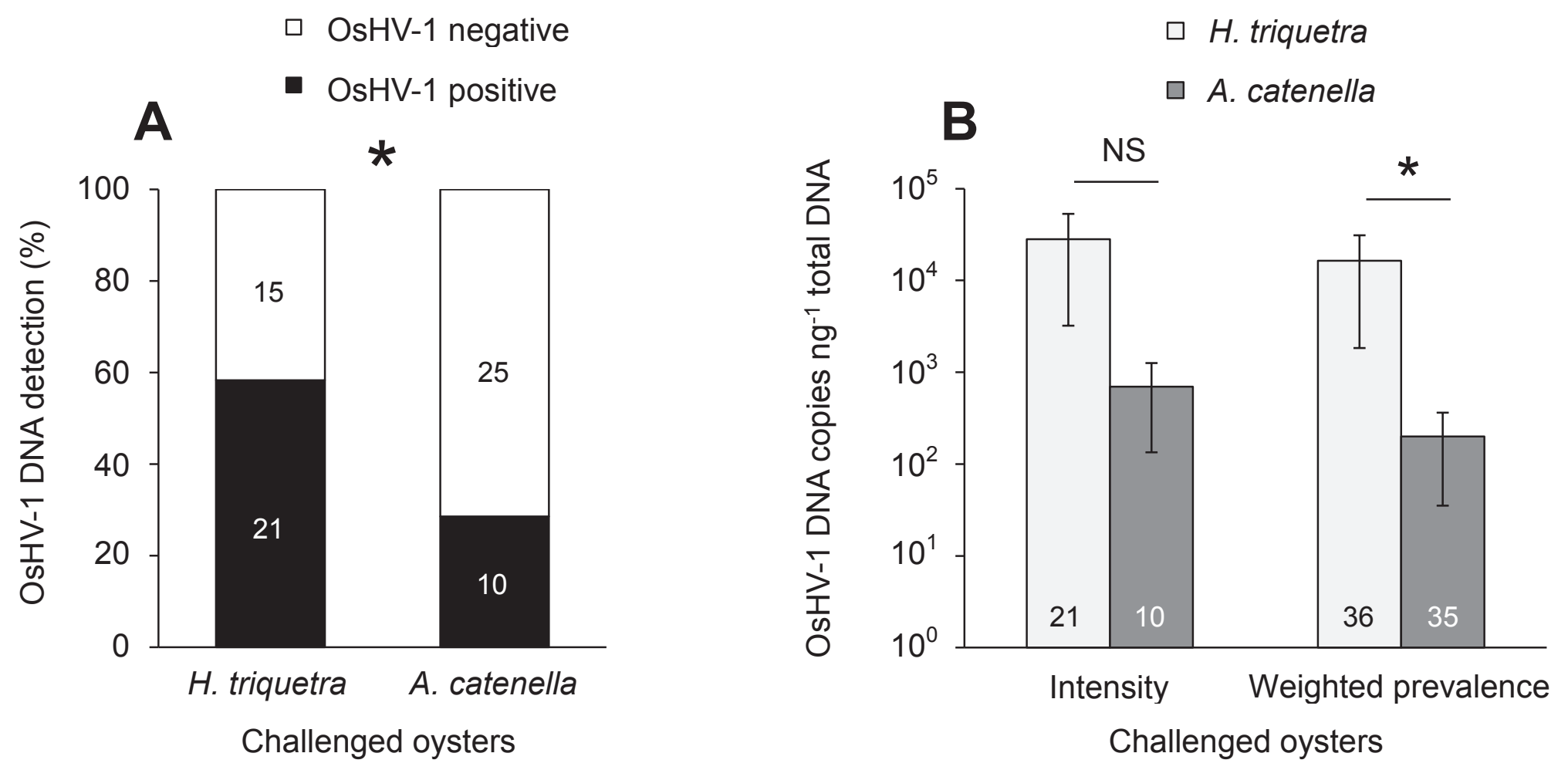
